\title{
Laju enkapsulasi parasitoid Anagyrus lopezi (De Santis) (Hymenoptera: Encyrtidae) oleh kutu putih singkong Phenacoccus manihoti Matile-Ferrero (Hemiptera: Pseudococcidae)
}

\author{
Encapsulation rates of parasitoid Anagyrus lopezi (De Santis) \\ (Hymenoptera: Encyrtidae) by cassava mealybug, Phenacoccus \\ manihoti Matile-Ferrero (Hemiptera: Pseudococcidae)
}

\author{
Evie Adriani, Aunu Rauf*, Pudjianto \\ Departemen Proteksi Tanaman, Fakultas Pertanian, Institut Pertanian Bogor \\ Jalan Kamper, Kampus IPB Dramaga, Bogor 16680
}

(diterima Januari 2016, disetujui Agustus 2016)

\begin{abstract}
ABSTRAK
Parasitoid Anagyrus lopezi (De Santis) (Hymenoptera: Encyrtidae) didatangkan ke Indonesia pada awal tahun 2014 untuk mengendalikan kutu putih singkong, Phenacoccus manihoti MatileFerrero (Hemiptera: Pseudococcidae). Penelitian bertujuan mempelajari laju enkapsulasi parasitoid A. lopezi oleh berbagai instar P. manihoti. Pengamatan laju enkapsulasi dilakukan dengan memaparkan seekor parasitoid betina yang telah kawin pada kutu putih nimfa-1, $-2,-3$, dan imago didalam tabung mika selama 24 jam. Kutu putih kemudian dibedah dan diamati banyaknya telur parasitoid yang diletakkan serta yang terenkapsulasi. Hasil penelitian menunjukkan laju enkapsulasi agregat paling tinggi dilakukan oleh imago, yaitu 8,4\%, diikuti oleh nimfa-3 (5,8\%), nimfa-2 (3,1\%), dan nimfa-1 (1,1\%). Laju enkapsulasi efektif oleh imago 2,0\%, sedangkan oleh nimfa sekitar 1,0\%. Laju enkapsulasi yang rendah ini diyakini tidak akan mengurangi keefektifan parasitoid $A$. lopezi dalam pengendalian hayati kutu putih singkong $P$. manihoti di Indonesia.
\end{abstract}

Kata kunci: Anagyrus lopezi, enkapsulasi, kutu putih singkong, parasitoid, Phenacoccusmanihoti

\begin{abstract}
Parasitoid Anagyrus lopezi (De Santis) (Hymenoptera: Encyrtidae) was introduced into Indonesia in early 2014 to control the cassava mealybug, Phenacoccus manihoti Matile-Ferrero (Hemiptera: Pseudococcidae). The objective of study was to determine encapsulation rate of parasitoid $A$. lopezi by various host instars of P. manihoti. Observation of encapsulation rate was made by exposing a single mated female of parasitoid on mealybug nymph-1, -2, -3, and adult in a plastic cage for $24 \mathrm{~h}$. Mealybugs then were dissected and number of parasitoid eggs laid and those encapsulated were counted. Study revealed that rate of aggregate encapsulation was highest (8.4\%) by adults, followed by nymph-3 (5.8\%), nymph-2 (3.1\%), and nymph-1 (1.1\%). Rate of effective encapsulation by adults was $2.0 \%$, whereas by nymphs about $1.0 \%$. The low rate of encapsulation is believed not to reduce the effectiveness of parasitoid $A$. lopezi in the biological control of cassava mealybug $P$. manihoti in Indonesia.
\end{abstract}

Key words: Anagyruslopezi, cassava mealybug, encapsulation, parasitoid,Phenacoccusmanihoti

\footnotetext{
*Penulis korespondensi: Aunu Rauf. Departemen Proteksi Tanaman, Fakultas Pertanian, Institut Pertanian Bogor Jalan Kamper, Kampus IPB Dramaga, Bogor 16680, Tel/Faks: 0251-8621267, Email: aunu@indo.net.id.
} 


\section{PENDAHULUAN}

Kutu putih singkong, Phenacoccus manihoti Matile-Ferreo (Pseudococcidae: Hemiptera), merupakan hama yang berasal dari Amerika Selatan. Pada tahun 1972 hama ini terbawa masuk ke Afrika dan banyak menimbulkan kerusakan berat (Schulthess et al. 1991). Sekitar 35 tahun kemudian hama ini menyebar ke Asia. Negeri yang pertama kali diinvasi oleh kutu $P$. manihoti adalah Thailand, yaitu pada tahun 2008 (Winotai et al. 2010). Dua tahun kemudian (2010), kutu $P$. manihoti dilaporkan menyerang pertanaman singkong di Bogor (Muniappan et al. 2011).

Untuk mengendalikan kutu putih singkong, pada awal tahun 2014 Institut Pertanian Bogor melalui kerjasama dengan CIAT-Vietnam dan FAO Indonesia mendatangkan parasitoid Anagyrus lopezi (De Santis) (Encyrtidae: Hymenoptera) dari Thailand (Wyckhuys et al. 2014). Penelitian uji kekhususan inang yang dilakukan oleh Karyani et al. (2016) menunjukkan bahwa parasitoid A. lopezi bersifat spesifik inang, yaitu hanya memarasit kutu $P$. manihoti sehingga diharapkan akan mampu mengendalikan kutu putih singkong dengan baik. Namun demikian, selama penelitian berlangsung sering dijumpai adanya telur parasitoid yang terindikasi mengalami enkapsulasi (Karyani et al. 2016; Adriani 2016).

Enkapsulasi merupakan mekanisme umum pertahanan diri dari serangga inang sebagai respons terhadap keberadaan endoparasitoid atau organisme asing lainnya (van Driesche et al. 1986; Blumberg 1997). Dalam proses enkapsulasi, sel-sel darah (hemosit) inang membentuk selubung, seperti kapsul di sekeliling telur atau larva parasitoid (Wajnberg \& Ris 2009). Sebagai akibatnya, parasitoid yang dienkapsulasi dapat mengalami kematian karena kekurangan oksigen dan nutrisi, atau secara fisik terhambat perkembangannya (Blumberg 1997).

Enkapsulasi dapat berpengaruh buruk terhadap pengendalian hayati karena dapat menurunkan keefektifan parasitoid serta menghambat keberhasilan menetap dari parasitoid yang diintroduksikan (Blumberg et al. 2001). Kegagalan pengendalian hayati akibat tingginya enkapsulasi dilaporkan terjadi di Kanada pada parasitoid Mesoleius tenthredinis Morleyi (Hymenoptera:
Ichneumonidae) di dalam inang Pristiphora erichsonii (Hartig) (Hymenoptera: Thenthredinidae) (Muldrew 1953). Hal serupa dilaporkan pula di USA pada parasitoid Bathyplectes curculionis (Thomson) (Hymenoptera: Ichneumonidae) di dalam larva inang Hypera postica (Gyllenhal) (Coleoptera: Curculionidae) (Berberet et al. 2003). Di Australia, parasitoid Comperiella bifasciata Howard (Hymenoptera: Encyrtidae) dapat mengendalikan kutu Aonidiella citrina (Coquillett) dengan baik, tetapi tidak untuk kutu A. aurantii (Maskell) (Homoptera: Diaspididae). Sebagian besar parasitoid C. bifasciata di dalam kutu $A$. citrina berkembang normal dan mematikan inangnya, sedangkan di dalam inang A. aurantii serendah-rendahnya 59\% mengalami enkapsulasi (Brewer 1971). Selain itu, enkapsulasi dapat menentukan pemilihan inang yang sesuai untuk keperluan pembiakan massal parasitoid di laboratorium. Sebagai contoh, parasitoid Metaphycus swirskii Annecke \& Mynhardt (Hymenoptera: Encyrtidae) dapat memarasit kutu Coccus hesperidium L., Saissetia coffeae (Walker), dan Saissetia oleae (Olivier) (Homoptera: Coccidae) pada pertanaman jeruk. Namun, hanya yang disebut terakhir yang sesuai untuk digunakan dalam pembiakan massal parasitoid M. swirskii. Laju enkapsulasi telur M. swirskii oleh kutu $S$. coffeae dan $C$. hesperidium berturut-turut $78-94 \%$ dan $100 \%$, sedangkan oleh kutu S. oleae 0-11\% (Blumberg 1977). Dalam kaitan ini, kutu $S$. coffeae dan C. hesperidium tidak layak digunakan untuk pembiakan parasitoid M. swirskii (Blumberg 1997).

Laju enkapsulasi bervariasi bergantung pada spesies inang, umur atau instar inang, derajat superparasitime, tumbuhan inang, dan kondisi lingkungan tempat pembiakan serangga inang dan parasitoid (Salt 1963; Blumberg 1997). Penelitian ini bertujuan mempelajari laju enkapsulasi parasitoid $A$. lopezi oleh berbagai instar kutu putih $P$. manihoti, serta laju parasitisme dan superparasitisme yang menyertainya.

\section{BAHAN DAN METODE}

Penelitian dilakukan di Laboratorium Bionomi dan Ekologi Serangga, Departemen Proteksi Tanaman, Fakultas Pertanian, Institut Pertanian 
Bogor dari Agustus 2014 hingga Desember 2014. Selama penelitian berlangsung rata-rata suhu ruangan $\pm 27^{\circ} \mathrm{C}$ dan kelembaban relatif $\pm 60 \%$.

\section{Perbanyakan kutu putih $P$. manihoti}

Perbanyakan kutu putih $P$. manihoti menggunakan bibit singkong varietas Roti. Untuk keperluan ini, stek singkong dengan panjang sekitar $15 \mathrm{~cm}$ dimasukkan ke dalam ember plastik berisi air keran sebanyak $250 \mathrm{ml}$. Bibit singkong dibiarkan tumbuh selama tiga minggu hingga muncul daun. Selanjutnya, ovisak dan nimfa $P$. manihoti yang dikoleksi dari lapangan diinfestasikan pada bibit singkong dan dibiarkan berkembang biak di laboratorium. Bibit singkong yang mati diganti dengan yang baru, dan koloni kutu putih dipindahkan dari bibit yang mati ke bibit yang masih segar, demikian seterusnya.

\section{Perbanyakan parasitoid $A$. lopezi}

Pembiakan parasitoid A. lopezi menggunakan kutu putih nimfa-3. Untuk maksud tersebut, nimfa-1 yang diperoleh dari hasil pembiakan dipelihara pada bibit singkong. Dua minggu setelah diinfestasikan, kutu putih telah berkembang menjadi nimfa-3 dan siap digunakan untuk pembiakan parasitoid $A$. lopezi. Selanjutnya, bibit singkong dengan kutu putih nimfa-3, dimasukkan ke dalam wadah plastik $(\mathrm{t}=12,5 \mathrm{~cm}, \mathrm{~d}=9 \mathrm{~cm})$ yang telah diisi air. Agar bibit singkong tumbuh tegak, bagian atas dari wadah diberi stiroform yang telah dilubangi sebesar batang singkong. Wadah kemudian dimasukkan ke dalam kurungan pembiakan berkerangka kayu. Kurungan berukuran $50 \mathrm{~cm} \times 45 \mathrm{~cm} \times 45 \mathrm{~cm}$ yang bagian sampingnya terbuat dari kain kasa dan bagian atasnya dari lembaran plastik. Pada salah satu dinding samping terdapat pintu berukuran $15 \mathrm{~cm}$ x $15 \mathrm{~cm}$ untuk memasukkan bibit singkong. Pada permukaan bagian dalam dari atap kurungan digantungkan kapas yang telah diresapi larutan madu $10 \%$ sebagai makanan imago parasitoid. $\mathrm{Ke}$ dalam kurungan pembiakan tadi lalu dimasukkan sekitar 50 pasang imago parasitoid A. lopezi. Setelah sekitar dua minggu, tanaman yang telah kering dan juga terdapat mumi $A$. lopezi dikumpulkan dan dimasukkan ke dalam kurungan plastik berukuran $20 \mathrm{~cm}$ x $20 \mathrm{~cm}$ x $25 \mathrm{~cm}$. Imago parasitoid yang muncul lalu dikumpulkan dengan aspirator dan digunakan kembali untuk pembiakan atau untuk keperluan percobaan.

\section{Penyiapan serangga percobaan}

Untuk memperoleh nimfa kutu putih instar tertentu dengan umur seragam dilakukan prosedur sebagai berikut. Nimfa-1 P. manihoti yang baru keluar dari telur, yang diperoleh dari kurungan pembiakan, dimasukkan ke dalam kurungan kecil berbentuk tabung $(t=47 \mathrm{~cm}, d=14 \mathrm{~cm})$ yang terbuat dari mika yang berisi bibit singkong berumur tiga minggu. Lima hari kemudian, nimfa- 1 tersebut telah berubah menjadi nimfa-2 yang siap digunakan untuk percobaan enkapsulasi. Prosedur yang sama dilakukan untuk mendapatkan nimfa-3 dan imago, yaitu dengan membiarkan nimfa-1 berkembang berturut-turut selama 10 dan 15 hari. Acuan masa perkembangan setiap instar $P$. manihoti didasarkan pada hasil penelitian Saputro (2013).

Imago parasitoid A. lopezi untuk keperluan percobaan enkapsulasi disiapkan sebagai berikut. Mumi kutu putih dikumpulkan dari kurungan pembiakan parasitoid dan disimpan di dalam kurungan plastik. Setiap hari imago parasitoid jantan dan betina yang muncul pada hari yang sama dipindahkan ke dalam kurungan kopulasi, yang terbuat dari wadah plastik berukuran $20 \mathrm{~cm}$ x $20 \mathrm{~cm}$ x $25 \mathrm{~cm}$, dan dibiarkan selama 1-2 hari. Bagian atas kurungan kopulasi terbuat dari kain kasa. Dilaporkan bahwa parasitoid dari Famili Encyrtidae umumnya melakukan perkawinan tidak lama setelah muncul dari mumi (Noyes \& Hayat 1994; Riherd 1950).

\section{Pemaparan inang pada parasitoid}

Masing-masing 10 individu nimfa-1, -2, -3 , dan imago $P$. manihoti secara terpisah diinfestasikan, dengan bantuan kuas halus, pada sehelai daun singkong. Daun singkong tersebut lalu dimasukkan ke dalam tabung mika $(\mathrm{t}=7 \mathrm{~cm}$, $\mathrm{d}=10 \mathrm{~cm})$. Bagian atas tabung, yang juga terbuat dari mika, diberi lubang $(p=4 \mathrm{~cm}, 1=4 \mathrm{~cm})$ yang ditutupi kain organdi sebagai ventilasi. Selanjutnya 1 individu imago betina $A$. lopezi berumur 1-2 hari yang berasal dari kurungan kopulasi dimasukkan ke dalam setiap tabung. Pada dinding tabung dioleskan setetes madu takaran $0,25 \mathrm{ml}$ sebagai sumber makanan parasitoid. 
Setelah 24 jam, parasitoid dikeluarkan dan kutu putih dibiarkan hidup hingga 24 jam berikutnya. Percobaan dilakukan sebanyak 20 ulangan untuk setiap instar kutu putih. Dengan demikian, secara keseluruhan percobaan ini menggunakan 800 individu kutu $P$. manihoti dan 80 individu imago betina parasitoid $A$. lopezi.

Dua hari setelah kutu putih dipaparkan terhadap parasitoid, lalu dilakukan pembedahan untuk menghitung dan memeriksa kondisi telur parasitoid yang ada di dalamnya. Untuk maksud tersebut, setiap kutu putih diambil dari daun, diletakkan di atas gelas objek, kemudian diberi setetes larutan fisiologis $(\mathrm{NaCl})$. Pembedahan menggunakan jarum mikro dan dilakukan di bawah mikroskop stereo. Banyaknya telur yang ditemukan pada masing-masing instar inang dicatat, serta dibedakan antara telur yang dienkapsulasi dan yang tidak. Hanya telur yang dienkapsulasi secara sempurna yang dikategorikan sebagai yang terenkapsulasi. Telur yang demikian dicirikan oleh adanya lapisan hitam pada seluruh permukaan telur.

Peubah yang diamati meliputi (a) banyaknya telur yang diletakkan oleh parasitoid per kutu putih yang terparasit, (b) banyaknya telur parasitoid yang terenkapsulasi per kutu putih yang terparasit, (c) enkapsulasi agregat, yaitu persentase telur parasitoid yang terenkapsulasi yang terdapat pada kutu putih yang terparasit, dan (d) enkapsulasi efektif, yaitu persentase kutu putih terparasit yang berhasil mengenkapsulasi seluruh telur parasitoid yang ada di dalam tubuhnya sehingga tidak ada satu pun telur atau larva parasitoid yang berhasil berkembang menjadi imago. Penentuan enkapsulasi agregat dan efektif didasarkan pada kriteria Blumberg \& van Driesche (2001). Selain itu, dicatat pula laju parasitisme, yaitu persentase inang terparasit, dan laju superparasitisme, yaitu persentase inang terparasit dengan dua atau lebih telur parasitoid di dalamnya.

\section{Analisis data}

Analisis ragam dilakukan untuk menguji pengaruh perbedaan instar inang terhadap laju enkapsulasi, parasitisme, dan superparasitisme, yang dilanjutkan dengan uji Tukey pada taraf 5\%. Sebelum dianalisis, data persentase ditransformasi ke nilai arcsin. Seluruh analisis dilakukan dengan bantuan program SPSS 16.0.

\section{HASIL}

Telur parasitoid yang tidak terenkapsulasi tampak transparan (Gambar 1A), yang terenkapsulasi sebagian dicirikan oleh adanya bagian berwarna hitam (Gambar 1B), sedangkan yang terenkapsulasi sempurna seluruh permukaannya tampak berwarna hitam (Gambar 1C). Dalam beberapa pengamatan pernah pula dijumpai adanya larva parasitoid yang terenkapsulasi. Seperti pada telur, larva yang tidak terenkapsulasi tampak transparan (Gambar 2A), sedangkan yang terenkapsulasi tampak berwarna hitam (Gambar 2B). Seringkali, tanpa harus melakukan pembedahan, keberadaan telur atau larva parasitoid yang terenkapsulasi dapat dikenali dari bayangan bintik hitam yang terdapat di dalam tubuh kutu putih (Gambar 3).

Laju enkapsulasi agregat paling tinggi terdapat pada imago $(8,40 \%)$, berbeda sangat nyata dengan
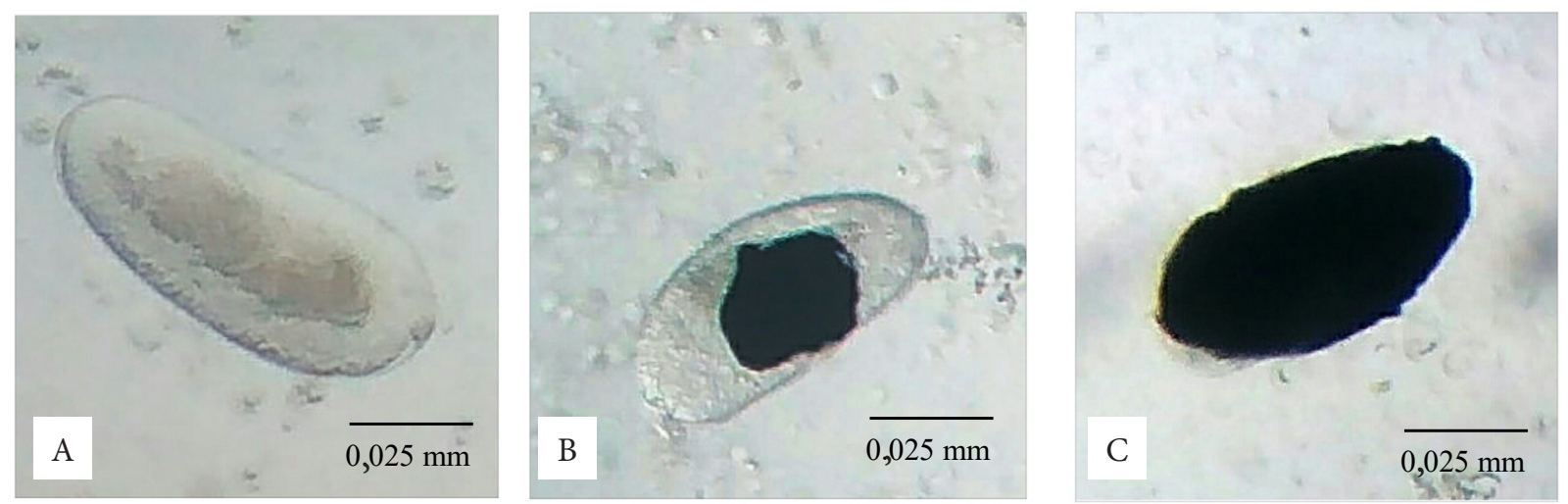

Gambar 1.Telur Anagyrus lopezi.A:tidak terenkapsulasi;B:terenkapsulasi sebagian; C:terenkapsulasi sempurna. 
pada nimfa-1 $(1,10 \%)$, namun tidak berbeda nyata dengan nimfa-2 $(3,10 \%)$ dan nimfa-3 $(5,80 \%)$ $\left(\mathrm{F}_{3,79}=3,564 ; \mathrm{P}=0,018\right)$. Dari total 257 butir telur parasitoid yang diletakkan di dalam tubuh imago kutu putih, sebanyak 25 butir mengalami enkapsulasi. Jumlah yang lebih rendah terdapat pada stadia nimfa, khususnya nimfa-1 (Tabel 1).

Laju enkapsulasi efektif tidak berbeda nyata $\left(\mathrm{F}_{3,79}=0,105 ; \mathrm{P}=0,957\right)$ antara berbagai instar inang, dengan nilai berkisar antara $1 \%-2 \%$ (Tabel 1). Dari 163 individu imago kutu putih yang terparasit, hanya 3 individu yang terenkapsulasi

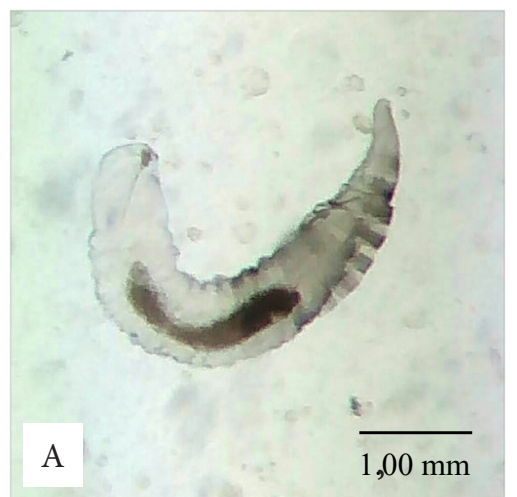

secara efektif. Begitu pula pada stadia nimfa, yang terenkapsulasi efektif tidak lebih dari 2 individu (Tabel 1).

Dari 55 individu kutu putih nimfa-1 yang terparasit, sebanyak $90,9 \%$ berisi 1 butir, dan sisanya berisi 2 butir (7,3\%) dan 3 butir (1,8\%) telur parasitoid (Tabel 2). Pada instar-instar berikutnya proporsi kutu putih yang mengandung satu butir menurun, sedangkan yang mengandung dua butir atau lebih meningkat. Dari total 446 individu nimfa-2, -3 , dan imago yang terparasit, proporsi yang mengandung satu butir telur

Gambar 2. Larva Anagyrus lopezi. A: tidak terenkapsulasi; dan B: terenkapsulasi sempurna.

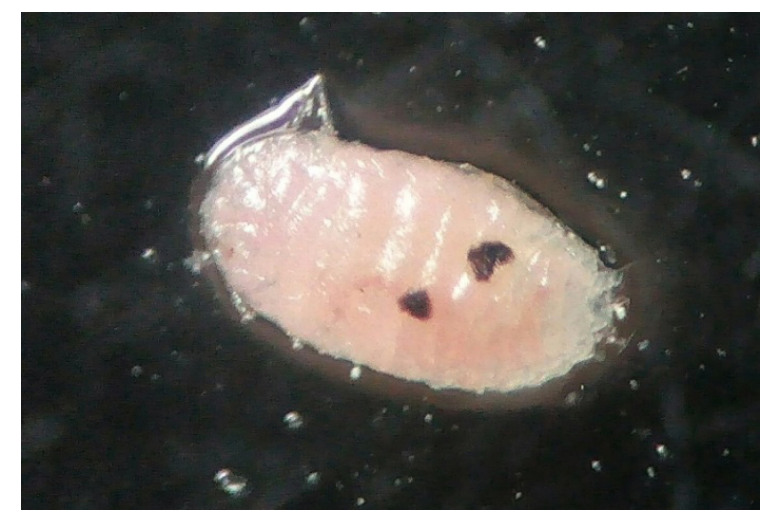

Gambar 3. Kutu putih Phenacoccus manihoti yang di dalam tubuhnya terdapat telur atau larva parasitoid yang terenkapsulasi (berwarna hitam).

Tabel 1. Laju enkapsulasi agregat dan efektif $(\mathrm{x} \pm \mathrm{SD}$ ) parasitoid Anagyrus lopezi oleh kutu putih Phenacoccus manihoti

\begin{tabular}{lcccc}
\hline \multirow{2}{*}{ Laju enkapsulasi } & \multicolumn{4}{c}{ Instar inang } \\
\cline { 2 - 5 } & Nimfa-1 & Nimfa-2 & Nimfa-3 & Imago \\
\hline \multirow{2}{*}{ Agregat (\%) } & $1,10 \pm 0,00 \mathrm{a}^{*}$ & $3,10 \pm 0,10 \mathrm{ab}$ & $5,80 \pm 0,10 \mathrm{ab}$ & $8,40 \pm 0,10 \mathrm{~b}$ \\
& $(1 / 74)^{* *}$ & $(8 / 199)$ & $(13 / 212)$ & $(25 / 257)$ \\
Efektif (\%) & $1,00 \pm 0,04 \mathrm{a}$ & $1,00 \pm 0,04 \mathrm{a}$ & $1,00 \pm 0,11 \mathrm{a}$ & $2,00 \pm 0,10 \mathrm{a}$ \\
& $(1 / 65)$ & $(2 / 143)$ & $(2 / 141)$ & $(3 / 167)$ \\
\hline
\end{tabular}

\footnotetext{
*Nilai pada baris yang sama yang diikuti oleh huruf yang sama tidak menunjukkan beda nyata (Uji Tukey $\alpha=5 \%$ ).

**Agregat: banyaknya telur yang terenkapsulasi/banyaknya telur di dalam kutu yang terparasit; Efektif: banyaknya kutu dengan seluruh telur terenkapsulasi/banyaknya kutu yang terparasit.
} 
parasitoid berkisar $60-70 \%$. Sisanya berisi 2 butir (17-25\%), 3 butir (5-12\%), dan $\geq 4$ butir (1-4\%). Bahkan dalam salah satu tubuh nimfa-3 pernah ditemukan 15 butir telur parasitoid.

Laju parasitisme $A$. lopezi pada imago, nimfa-2, dan nimfa-3 kutu putih berturut-turut $82 \%, 72 \%$, dan $71 \%$ (Tabel 3), lebih tinggi $\left(\mathrm{F}_{3,79}=50,63\right.$; $\mathrm{P}<0,001)$ dibandingkan pada nimfa-1 $(33 \%)$. Laju superparasitisme juga lebih tinggi pada imago (36\%) dan nimfa-2 (31\%) dibandingkan pada nimfa-3 (27\%), dan paling rendah terjadi pada nimfa-1 (18\%) $\left(\mathrm{F}_{3,79}=4,354 ; \mathrm{P}=0,007\right)$. Hal ini sejalan pula dengan laju peletakan telur. Rataan banyaknya telur yang diletakkan per inang terparasit pada nimfa-3 dan imago sekitar 1,6 butir, lebih tinggi $\left(\mathrm{F}_{3,84}=3,20 ; \mathrm{P}=0,028\right)$ dibandingkan pada nimfa-1 (1,1 butir) (Tabel 3).

\section{PEMBAHASAN}

Telur parasitoid $A$. lopezi yang terenkapsulasi dapat dikenali dari permukaannya yang berwarna gelap atau hitam, sebagai akibat dari terjadinya melanisasi pada kapsul hemosit inang yang menyelubungi parasitoid (Blumberg 1997). Sagarra et al. (2000) menguraikan proses enkapsulasi telur parasitoid Anagyrus kamali Moursi
(Hymenoptera: Encyrtidae) oleh inangnya kutu Maconellicoccus hirsutus Green (Homoptera: Pseudococcidae). Gejala awal dari enkapsulasi telur adalah terbentuknya lapisan berwarna jingga atau kuning sawo yang menyelimuti telur. Gejala selanjutnya adalah terbentuknya pigmen melanin berupa bercak hitam, yang kemudian menyebar ke seluruh permukaan telur. Pada keadaan demikian, telur parasitoid telah terenkapsulasi secara sempurna sehingga dapat mengalami kematian (Blumberg 1997). Selama penelitian berlangsung, sering dijumpai adanya telur yang permukaannya terenkapsulasi sebagian (partial encapsulation). Parasitoid yang terenkapsulasi secara tidak sempurna ini umumnya masih dapat hidup dan berkembang dengan normal (van den Bosch 1964).

Seluruh instar P. manihoti memiliki kemampuan untuk mengenkapsulasi telur A. lopezi, tetapi dengan laju yang berbeda-beda. Secara umum enkapsulasi parasitoid A. lopezi lebih banyak terjadi oleh imago $P$. manihoti dibandingkan oleh nimfa. Hal serupa dilaporkan pula pada A. kamali yang memarasit kutu putih $M$. hirsutus (Sagarra et al. 2000). Hal ini terjadi karena sistem pertahanan diri pada imago telah lebih berkembang sempurna dibandingkan pada nimfa yang berukuran kecil (Sagarra et al. 2000). Menurut Souissi \& Le Ru (1998) inang yang berumur tua lebih berhasil

Tabel 2. Distribusi banyaknya telur parasitoid Anagyrus lopezi yang diletakkan di dalam tubuh kutu putih Phenacoccus manihoti

\begin{tabular}{lcccc}
\hline $\begin{array}{l}\text { Banyaknya telur parasitoid yang } \\
\text { diletakkan per inang }\end{array}$ & \multicolumn{4}{c}{ \% banyaknya telur menurut instar inang } \\
\cline { 2 - 5 } (butir) & $\begin{array}{c}\text { Nimfa-1 } \\
(\mathrm{n}=55)\end{array}$ & $\begin{array}{c}\text { Nimfa-2 } \\
(\mathrm{n}=142)\end{array}$ & $\begin{array}{c}\text { Nimfa-3 } \\
(\mathrm{n}=138)\end{array}$ & $\begin{array}{c}\text { Imago } \\
(\mathrm{n}=166)\end{array}$ \\
\hline 1 & 90,9 & 69,0 & 73,2 & 61,4 \\
2 & 7,3 & 24,7 & 17,4 & 23,5 \\
3 & 1,8 & 4,9 & 5,8 & 12,1 \\
$\geq 4$ & 0 & 1,4 & 3,6 & 3,0 \\
\hline
\end{tabular}

Tabel 3. Laju parasitisme, superparasitisme, dan banyaknya telur yang diletakkan ( \pm SD) parasitoid Anagyrus lopezi pada kutu putih Phenacoccus manihoti

\begin{tabular}{lcccc}
\hline \multirow{2}{*}{ Parameter } & \multicolumn{4}{c}{ Inang } \\
\cline { 2 - 5 } & Nimfa-1 & Nimfa-2 & Nimfa-3 & Imago \\
\hline Laju parasitisme (\%) & $32,50 \pm 0,19 \mathrm{a}^{*}$ & $71,50 \pm 0,10 \mathrm{~b}$ & $70,50 \pm 0,10 \mathrm{~b}$ & $81,50 \pm 0,11 \mathrm{~b}$ \\
Laju superparasitisme (\%) & $17,70 \pm 0,44 \mathrm{a}$ & $31,00 \pm 0,23 \mathrm{~b}$ & $27,40 \pm 0,24 \mathrm{ab}$ & $35,60 \pm 0,26 \mathrm{~b}$ \\
$\begin{array}{l}\text { Rataan banyaknya telur per } \\
\text { inang terparasit (butir) }\end{array}$ & $1,09 \pm 0,34 \mathrm{a}$ & $1,39 \pm 0,34 \mathrm{ab}$ & $1,57 \pm 0,99 \mathrm{~b}$ & $1,55 \pm 0,44 \mathrm{~b}$ \\
\hline
\end{tabular}

*Nilai pada baris yang sama yang diikuti oleh huruf yang sama tidak menunjukkan beda nyata (Uji Tukey $\alpha=5 \%$ ). 
melakukan enkapsulasi daripada yang muda karena memiliki jumlah hemosit yang lebih banyak (Souissi \& Le Ru 1998). Dalam kaitan ini, parasitoid dapat menghindari enkapsulasi dengan cara memilih kutu putih instar awal untuk tempat peletakan telur (Sagarra et al. 2000).

Kebanyakan anggota Famili Encyrtidae yang memarasit kutu putih merupakan parasitoid soliter (Noyes \& Hayat 1994). Hal ini terjadi pula pada $A$. lopezi, hanya satu individu parasitoid yang berhasil berkembang di dalam setiap tubuh inang. Namun demikian, superparasitisme umum terdapat pada Encyrtidae yang memarasit kutu putih (Noyes \& Hayat 1994). Hasil pembedahan inang P. manihoti menunjukkan rataan banyaknya telur $A$. lopezi yang diletakkan per inang lebih dari 1 butir. Kutu putih $P$. manihoti yang berukuran lebih besar, seperti imago dan nimfa-3, lebih banyak diletaki telur oleh parasitoid $A$. lopezi daripada yang berukuran kecil, seperti nimfa-1. Pada penelitian ini, kejadian superparasitisme pada imago sekitar $40 \%$, sementara pada nimfa-1 sekitar $10 \%$. Pada inang yang mengalami superparastisme, tidak semua telur parasitoid berhasil dienkapsulasi sehingga satu atau lebih di antaranya dapat terhindar dari enkapsulasi dan berkembang normal menjadi larva (Giordanengo \& Nenon 1990). Tampaknya terdapat hubungan antara banyaknya telur parasitoid yang diletakkan (superparasitisme) dan tingkat resistensi inang, yang ditunjukkan oleh banyaknya telur yang terenkapsulasi maupun oleh laju enkapsulasi agregat dan efektif. Hasil penelitian Blumberg et al. (2001) mendapatkan bahwa laju enkapsulasi efektif Anagyrus pseudococci (Girault) (Hymenoptera: Encyrtidae) oleh Planococcus citri (Risso) (Hemiptera: Pseudococcidae) jauh lebih tinggi (76,6\%) pada inang yang berisi satu telur dibandingkan pada inang yang berisi beberapa telur (18,8\%). Hal ini mendukung hipotesis bahwa superparasitisme digunakan oleh parasitoid sebagai strategi untuk mengatasi respons pertahanan diri dari inang (Blumberg et al. 2001).

Enkapsulasi parasitoid oleh inang merupakan parameter penting yang memengaruhi kesesuaian musuh alami dan keberhasilan pengendalian hayati (Blumberg 1997). Suma et al. (2011) mendapatkan laju enkapsulasi agregat dan efektif pada Anagyrus sp. nr. pseudococci oleh kutu putih $P$. citri berturut-turut $75 \%$ dan $60 \%$. van Driesche et al. (1986) mendapatkan laju enkapsulasi yang lebih rendah (3-15\%) pada parasitoid Epidinocarsis diversicornis (Howard) (Hymenoptera: Encyrtidae) oleh inangnya kutu putih Phenacoccus herreni Cox \& Williams (Hemiptera: Psedudococcidae). Laju enkapsulasi yang juga rendah $(11,8 \%)$ dilaporkan pada parasitoid A. lopezi oleh P. manihoti (Giordanengo \& Nenon 1990). Di dalam penelitian yang kami lakukan, laju enkapsulasi agregat dan laju enkapsulasi efektif parasitoid $A$. lopezi oleh kutu putih $P$. manihoti berturut-turut $8,4 \%$ dan $2,0 \%$. Menurut Blumberg et al. (2001) laju enkapsulasi yang rendah umumnya terjadi pada inang yang diparasit oleh parasitoid yang berasal dari daerah geografis yang sama dengan inangnya. Parasitoid A. lopezi dan kutu putih P. manihoti keduanya berasal dari Paraguay/Brazil (Lema \& Herren 1985). Laju enkapsulasi yang rendah, seperti dilaporkan dalam tulisan ini, merupakan sesuatu yang menguntungkan ditinjau dari segi pengendalian hayati. Pembiakan massal A. lopezi serta keefektifan parasitoid dalam menekan populasi kutu P. manihoti di lapangan diyakini tidak akan banyak terpengaruh oleh enkapsulasi.

\section{KESIMPULAN}

Laju enkapsulasi agregat $A$. lopezi tertinggi terjadi pada inang stadia imago, sejalan dengan lebih tingginya laju superparasitisme. Laju enkapsulasi efektif tergolong sangat rendah (2\%). Dengan demikian, keefektifan parasitoid $A$. lopezi dalam pengendalian hayati kutu putih singkong P. manihoti diyakini tidak akan terpengaruh oleh enkapsulasi.

\section{UCAPAN TERIMA KASIH}

Penelitian ini merupakan bagian dari rangkaian penelitian yang dilakukan oleh penulis pertama dalam rangka menyelesaikan studi S2 pada Program Studi Entomologi di Institut Pertanian Bogor, dengan Beasiswa dari BPPDN (Beasiswa Pendidikan Pascasarjana Dalam Negeri), Direktorat Jenderal Pendidikan TinggiKementerian Ristek dan Pendidikan Tinggi. 


\section{DAFTAR PUSTAKA}

Adriani E. 2016. Preferensi, Kesesuaian dan Parasitisme Anagyrus lopezi (De Santis) (Hymenoptera: Encyrtidae) pada Berbagai Instar Kutu Putih Singkong, Phenacoccus manihoti Matile-Ferrero (Hemiptera: Pseudococcidae). Tesis. Bogor: Institut Pertanian Bogor.

Berberet RC, Zarrabi AA, Payton ME, Bisges AD. 2003. Reduction in effective parasitism of Hypera postica (Coleoptera: Curculionidae) by Bathyplectes curculionis (Hymenoptera: Ichneumonidae) due to encapsulation. Environmental Entomology 32:1123-1130. doi: https://doi. org/10.1603/0046-225X-32.5.1123.

Blumberg D. 1997. Parasitoid encapsulation as a defense mechanism in the Coccoidea (Homoptera) and its importance in biological control. Biological Control 8:225-236. doi: https://doi. org/10.1006/bcon.1997.0502.

Blumberg D, Franco JC, Suma P, Russo A, Mendel Z. 2001. Parasitoid encapsulation in mealybugs (Hemiptera: Pseudococcidae) as affected by the host-parasitoid association and superparasitism. Bollettino di Zoologia Agraria e di Bachicoltura 33:385-395.

Blumberg D, van Driesche RG. 2001. Encapsulation rates of three Encyrtid parasitoids by three mealybug spesies (Homoptera: Pseudococcidae) found commonly as pests in commercial greenhouse. Biological Control 22:191-199. doi: https://doi.org/10.1006/bcon.2001.0966.

Brewer RH. 1971. The influence of the parasite Comperiella bifasciata How. on the populations of two species of armored scale insects, Aonidiella aurantii (Mask.) and A. citrina (Coq.) in South Australia. Australian Journal of Zoology 19:53-63. doi: https://doi.org/10.1071/ ZO9710053.

Giordanengo P, Nenon JP. 1990. Melanization and encapsulation of eggs and larvae of Epidinocarsis lopezi by its host Phenacoccus manihoti; effects of superparasitism and egg laying patterns. Entomologia Experimentalis et Applicata 56:155-163. doi: https://doi. org/10.1111/j.1570-7458.1990.tb01393.x.

Karyani RD, Maryana N, Rauf A. 2016. Pengujian kekhususan inang parasitoid Anagyrus lopezi (De Santis) (Hymenoptera: Encyrtidae) pada empat spesies kutu putih yang berasosiasi dengan tanaman singkong. Jurnal Entomologi Indonesia 13:30-39. doi: http://dx.doi.org/10.5994/ jei.13.1.30.
Lema KM, Herren HR. 1985. Release and establishment in Nigeria of Epidinocarsis lopezi, a parasitoid of the cassava mealybug, Phenacoccus manihoti. Entomologia Experimentalis et Applicata 38:171-175. doi: https://doi.org/10.1111/j.1570-7458.1985. tb03515.x.

Muldrew JA. 1953. The natural immunity of the larch sawfly Pristiphora erichsonii (Htg.) to the introduced parasite, Mesoleius thenthredinis Morley in Saskatchewan. Canadian Journal of Zoology 31:313-332. doi: https://doi. org/10.1139/z53-025.

Muniappan R, Shepard BM, Watson GW, Carner GR, Rauf A, Sartiami D, Hidayat P, Afun JVK, Goergen G, Rahman AKMZ. 2011. New records of invasive insects (Hemiptera: Sternorrhyncha) in Southern Asia and West Africa. Journal of Agricultural and Urban Entomology 26:167-174. doi: https://doi.org/10.3954/15235475-26.4.167.

Noyes JS, Hayat M. 1994. Oriental Mealybug Parasitoids of the Anagyrini (Hymenoptera: Encyrtidae. London, UK: CABI.

Riherd PT. 1950. Biological notes on Anagyrus antoninae Timberlake (HymenopteraEncyrtidae) and its host Antonina graminis (Maskell) (Homoptera-Coccidae). Florida Entomologist 33:18-22.

Sagarra LA, Peterkin DD, Vincent C, Stewart RK. 2000. Immune response of the hibiscus mealybug, Maconellicoccus hirsutus Green (Homoptera: Pseudococcidae), to oviposition of the parasitoid Anagyrus kamali Moursi (Hymenoptera: Encyrtidae). Journal of Insect Physiology 46:647-653. doi: https://doi. org/10.1016/S0022-1910(99)00152-3.

Salt G. 1963. The defence reactions of insects to metazoan parasites. Parasitology 53:527-642. doi: https://doi.org/10.1017/ S0031182000073960.

Saputro AR. 2013. Biologi dan Potensi Peningkatan Populasi Kutu Putih Singkong, Phenacoccus manihoti Matile-Ferrero (Hemiptera: Pseudococcidae), Hama Pendatang Baru di Indonesia. Skripsi. Bogor: Institut Pertanian Bogor.

Schulthess F, Baumgartner JU, Delucchi V, Guttierez AP. 1991. The influence of the cassava mealybug, Phenacoccus manihoti Mat-Ferr (Homoptera: Pseudococcidae) on yield formation of cassava, Manihot esculenta Crantz. Journal of Applied Entomology 111:155-165. doi: https://doi. org/10.1111/j.1439-0418.1991.tb00306.x. 
Souissi R, Le Ru B. 1998. Influence of the host plant of the cassava mealybug Phenacoccus manihoti (Hemiptera: Pseudococcidae) on biological characteristics of its parasitoid Apoanagyrus lopezi (Hymenoptera: Encyrtidae). Bulletin of Entomological Research 88:75-85. doi: https:// doi.org/10.1017/S0007485300041572.

Suma P, Mansour R, Russo A, Torre IL, Bugila AAA, Franco JC. 2011. Encapsulation rates of the parasitoid Anagyrus sp. nr pseudococci, by three mealybug species (Hemiptera: Pseudococcidae). Phytoparasitica 40:11-16. doi: 10.1007/s12600011-0199-8. doi: https://doi.org/10.1007/ s12600-011-0199-8.

van den Bosch R. 1964. Encapsulation of the eggs of Bathyplectes cuculionis (Thomson) (Hymenoptera: Ichneumonidae) in larvae of Hypera brunneipennis (Boheman) and Hypera postica (Gyllenhal) (Coleoptera: Curculionidae). Journal of Insect Pathology 6:343-367. van Driesche RG, Belloti A, Herrera CJ, Castilo JA. 1986. Encapsulation rates of two encyrtids parasitoids by two Phenacoccus spp of cassava mealybugs in Colombia. Entomologia Experimentalis et Applicata 42:79-82. doi: https://doi.org/10.1111/j.1570-7458.1986. tb02190.x.

Wajnberg E, Ris N. 2009. Parasitism and biological control. In: Thomas F, Fuegan JF, Renaud F (Eds.), Ecology and Evolution Parasitism. pp. 107-127. Oxford: Oxford University Press.

Winotai A, Goergen G, Tamo M, Neuenschwander P. 2010. Cassava mealybug has reached Asia. Biocontrol News and Information 31:10-11.

Wyckhuys KAG, Rauf A, Ketelaar J. 2014. Parasitoid introduced into Indonesia: Part of a region-wide campaign to tackle emerging cassava pests and diseases. Biocontrol News and Information 35:35-37. 